\title{
Effect of Different Establishment Techniques and Planting Geometry on Nutrient Content, Uptake and Soil Fertility Status after Harvest of Sugarcane
}

\author{
Maruthi, D. Krishnamurthy ${ }^{*}$, Y.M. Ramesh, B.M. Chittapur and Ashokkumar Gaddi
}

University of Agricultural Sciences, Raichur - 584 104, Karnataka, India

*Corresponding author

Keywords

Availability,

Sugarcane, Setts,

Geometry, Uptake

and Nutrient status

Article Info

Accepted:

04 September 2018

Available Online:

10 October 2018
A B S T R A C T

A Field experiment was carried out in a black clay [the soil was slightly alkaline $\mathrm{pH}$ (8.23), low in EC $\left(0.20 \mathrm{dSm}^{-1}\right)$ and organic carbon $(0.43 \%)$, low in available nitrogen $\left(166.8 \mathrm{~kg} \mathrm{ha}^{-1}\right)$, high in available phosphorus $\left(55.0 \mathrm{~kg} \mathrm{ha}^{-1}\right)$ and available potassium $(300.5$ $\left.\mathrm{kg} \mathrm{ha}^{-1}\right)$ ] to study the effect of Effect of different establishment techniques and planting geometry on uptake of nutrients and soil fertility status after harvest of sugarcane at Experimental block, Agricultural Research Station, Dhadesugur which falls under Northern Dry Zone of Karnataka (Zone-III) during 2016-17. Planting of two eye budded setts with dual row planting of sugarcane recorded numerically higher $\mathrm{N}$ and $\mathrm{K}$ uptake (337.4, 79.1 and $341.6 \mathrm{~kg} \mathrm{ha}^{-1}$, respectively) followed by two eye budded setts with paired row planting (308.9, 72.4 and $310.1 \mathrm{~kg} \mathrm{ha}^{-1}$, respectively) and two eye budded setts with wide row planting (289.5, 69.1 and $297.7 \mathrm{~kg} \mathrm{ha}^{-1}$, respectively). Lower uptake was noticed in three eye budded setts with normal row planting $\left(221.3,54.6\right.$ and $240.3 \mathrm{~kg} \mathrm{ha}^{-1}$, respectively). Under different establishment techniques and planting geometries, growing sugarcane did not significantly influence the available soil nutrients at harvest. However, three eye budded setts with normal planting recorded numerically higher $\mathrm{N}, \mathrm{P}$ and $\mathrm{K}$ availability followed by chip bud setts with wide row planting. Lower N, P and K availability was recorded in two eye budded setts with dual row planting.

\section{Introduction}

Sugarcane (Saccharum officinarum L.) is an important commercial crop and it provides sugar, bio-fuel and manure besides many by products. In the world, there are 115 countries cultivating sugarcane with a sugar production of $1331.2 \mathrm{~m} \mathrm{t}$ which is three fourth of the total sugar production of the world (Anon., 2015b) and remaining sugar is derived from sugar beet $(21.5 \%)$. Globally, sugarcane is cultivated in an area of $24.5 \mathrm{~m}$ ha with a production of
$1850 \mathrm{~m} \mathrm{t}$ and a productivity of $75.5 \mathrm{t} \mathrm{ha}^{-1}$ (Anon, 2015). In India, sugarcane is grown in Maharashtra, Karnataka, Gujarat, Tamil Nadu, Uttar Pradesh, Punjab, Haryana and Bihar. India is the world's second largest producer of sugarcane in terms of area $(5.3 \mathrm{~m} \mathrm{ha})$ of world's total sugar production $(27.1 \mathrm{~m} \mathrm{t})$. In Karnataka, it is cultivated in an area of about $0.50 \mathrm{~m}$ ha with a production of $47 \mathrm{~m} \mathrm{t}$ and a productivity of $94.0 \mathrm{t} \mathrm{ha}^{-1}$ (Anon., 2015a). In Tunga Bhadra Project (TBP) command area, sugarcane is an important commercial crop 
after rice and cotton. Traditionally three budded cane setts were using for planting which consumes a lot of cane for planting alone and hence, greater financial burden for the grower from the beginning. Of late many techniques have been evolved for planting at different places like two budded setts, single eye budded setts, bud scoops and transplanting which require less planting material and hence more economical. However, these materials respond differentially to planting geometry to produce profitable yields and cane cultivars respond differentially to these methods. Some of the planting systems are evolved specifically for the purpose of convenience of cultural operations such as irrigation, wind damage management and suitability to machine harvesting.

The primary components of cane yield are cane population and weight of individual cane. Cane population per unit area is directly affected by planting density which changes rapidly with the closer spacing or with the increase in seed rate. Thus, yield level can be increased substantially by manipulating certain cultural practices like spacing, planting material etc. The adaption of optimum spacing, suitable planting pattern/ crop geometry, sett size and sett rate will go a long way in increasing yield and quality of sugarcane. The information on testing of different planting material under various planting techniques on nutrient uptake and soil fertility under TBP command area is lacking and needs to be worked out. It is, therefore, necessary to standardize the suitable planting techniques with spacing/ plant geometry that may improve the productivity and sustainability of sugarcane. Hence, the present study was planned and executed accordingly.

\section{Materials and Methods}

A Field experiment was carried out in a black clay [the soil was slightly alkaline $\mathrm{pH}$ (8.23), low in EC $\left(0.20 \mathrm{dSm}^{-1}\right)$ and organic carbon $(0.43 \%)$, low in available nitrogen $(166.8 \mathrm{~kg}$ $\left.\mathrm{ha}^{-1}\right)$, high in available phosphorus $(55.0 \mathrm{~kg}$ $\mathrm{ha}^{-1}$ ) and available potassium (300.5 $\left.\mathrm{kg} \mathrm{ha}^{-1}\right)$ ] to study the effect of Effect of different establishment techniques and planting geometry on uptake of nutrients and soil fertility status after harvest of sugarcane at Experimental block, Agricultural Research Station, Dhadesugur which falls under Northern Dry Zone of Karnataka (Zone-III) during 2016-17. The station is situated between $15^{\circ} 41^{\prime} \mathrm{N}$ latitude, $76^{\circ} 53^{\prime} \mathrm{E}$ longitude and at an altitude of 380 meters above mean sea level. The composite soil samples from 0 to $15 \mathrm{~cm}$ depth were collected before planting and at harvest. Soils were air dried in shade, powdered and passed through $2 \mathrm{~mm}$ sieve and analysed for $\mathrm{pH}, \mathrm{EC}, \mathrm{OC}$, available $\mathrm{N}, \mathrm{P}_{2} \mathrm{O}_{5}$ and $\mathrm{K}_{2} \mathrm{O}_{5}$ by following the methods described by Jackson (1973) and Lindsay and Norvel (1978). The experiment comprised of ten treatments viz. $\mathrm{T}_{1}$-Single eye budded setts with wide row planting (120 cm furrow), $\mathrm{T}_{2}$ : Single eye budded setts with paired row planting (60 $\mathrm{cm}-120 \mathrm{~cm}-60 \mathrm{~cm}), \mathrm{T}_{3}$ : Single eye budded setts with dual row planting $(30 \mathrm{~cm}-150 \mathrm{~cm}-$ $30 \mathrm{~cm}), \mathrm{T}_{4}$ : Two eye budded setts with wide row planting $(120 \mathrm{~cm}), \mathrm{T}_{5}$ : Two eye budded setts with paired row planting $(60 \mathrm{~cm}-120$ cm- $60 \mathrm{~cm}), \mathrm{T}_{6}$ : Two eye budded setts with dual row planting $(30 \mathrm{~cm}-150 \mathrm{~cm}-30 \mathrm{~cm}), \mathrm{T}_{7}$ : Bud chip seedlings with wide row planting (120 cm furrow), $\mathrm{T}_{8}$ : Bud chip seedlings with paired row planting $(60 \mathrm{~cm}-120 \mathrm{~cm}-60 \mathrm{~cm})$, $\mathrm{T}_{9}$ : Bud chip seedlings with dual row planting (30 cm- $150 \mathrm{~cm}-30 \mathrm{~cm}$ ) and $\mathrm{T}_{10}$ : Three eye budded setts with conventional planting (90 $\mathrm{cm})$. The experiment was laid out in randomized complete block design (RCBD) with three replications. The sugarcane variety 2003-V-46 was planted on $1^{\text {st }}$ of February, 2016. Fertilizer was applied @ $250 \mathrm{~kg} \mathrm{~N}, 100$ $\mathrm{kg}_{2} \mathrm{O}_{5}$ and $125 \mathrm{~kg} \mathrm{~K}_{2} \mathrm{O} \mathrm{ha}^{-1}$ in the form of Urea, DAP, and SOP, respectively. The entire dose of $\mathrm{P}, \mathrm{K}$, and $1 / 3$ rd of $\mathrm{N}$ were applied as a 
basal dose at the time of planting, while remaining $\mathrm{N}$ was applied in two splits, 1/3rd at the start of tillering and 1/3rd before earthing up by side dressing. The crop was harvested manually after its maturity on $29^{\text {th }}$ of February, 2017. Recommended packages of practices were adopted for crop production. The analysis and interpretation of data were done using the Fisher's method of analysis and variance technique as given by Gomez and Gomez (1984).

\section{Results and Discussion}

\section{Nutrient content and uptake by sugarcane}

Nitrogen content and uptake: The data on nitrogen content in leaf and cane of sugarcane as influenced by establishment techniques and planting geometries did not differ significantly (Table 1). However, the data on uptake of nitrogen by sugarcane as influenced by the establishment techniques and planting geometries was differed significantly. Among the treatments, growing of sugarcane with two eye budded setts with dual row planting (30 $\mathrm{cm}-150 \mathrm{~cm}-30 \mathrm{~cm}$ ) recorded significantly maximum uptake of nitrogen in leaf, cane and plant (133.2, 204.2 and $337.4 \mathrm{~kg} \mathrm{ha}^{-1}$, respectively) and it was on par with the two eye budded setts with paired row $(60 \mathrm{~cm}-120$ $\mathrm{cm}-60 \mathrm{~cm}$ ) planting (120.1, 188.8 and 308.9 $\mathrm{kg} \mathrm{ha}^{-1}$, respectively) and two eye budded setts with wide row $(120 \mathrm{~cm})$ planting $(111.2,178.1$ and $289.5 \mathrm{~kg} \mathrm{ha}^{-1}$, respectively).

However, uptake of nitrogen in leaf, cane and plant was on par with planting of sugarcane with single eye budded setts and bud chip seedling with different planting geometries. Whereas, planting of sugarcane with three budded setts (conventional planting) recorded significantly lower uptake of nitrogen in leaf, cane and plant $\left(78.1,143.2\right.$ and $221.3 \mathrm{~kg} \mathrm{ha}^{-1}$, respectively). Similar findings were reported by Patel (2003).
Phosphorus content and uptake: The data on nutrient content of phosphorus in sugarcane was not differed as influenced by the establishment techniques and planting geometries (Table 2). Results indicated that growing of sugarcane with two eye budded setts with dual row planting $(30 \mathrm{~cm}-150 \mathrm{~cm}$ $30 \mathrm{~cm}$ ) recorded significantly higher uptake of phosphorus in leaf, cane and plant (24.1, 55.0 and $79.1 \mathrm{~kg} \mathrm{ha}^{-1}$, respectively) and it was on par with the two eye budded setts with paired row $(60 \mathrm{~cm}-120 \mathrm{~cm}-60 \mathrm{~cm})$ planting $(21.4$, 51.0 and $72.4 \mathrm{~kg} \mathrm{ha}^{-1}$, respectively) and two eye budded setts with wide row $(120 \mathrm{~cm})$ planting (20.6, 48.4 and $69.1 \mathrm{~kg} \mathrm{ha} \mathrm{ha}^{-1}$, respectively).

However, uptake of phosphorus in leaf, cane and plant was on par with planting of sugarcane with single eye budded setts and bud chip seedling with different planting geometries. Whereas, planting of sugarcane with three budded setts (conventional planting) recorded significantly lower uptake of phosphorus in leaf, cane and plant (15.8, 38.8 and $54.6 \mathrm{~kg} \mathrm{ha}^{-1}$, respectively). Similar findings were reported by Patel (2003).

Potassium content and uptake: Potassium content in leaf and cane did not differ significantly (Table 3 ). The data on uptake of potassium in sugarcane as influenced by the establishment techniques and planting geometries were differed significantly.

Growing of sugarcane with two eye budded setts with dual row planting $(30 \mathrm{~cm}-150 \mathrm{~cm}-$ $30 \mathrm{~cm}$ ) recorded significantly maximum uptake of potassium in leaf, cane and plant $\left(160.5,181.0\right.$ and $341.6 \mathrm{~kg} \mathrm{ha}^{-1}$, respectively) and it was on par with the two eye budded setts with paired row $(60 \mathrm{~cm}-120 \mathrm{~cm}-60 \mathrm{~cm})$ planting (142.3, 167.7 and $310.1 \mathrm{~kg} \mathrm{ha}^{-1}$, respectively) and two eye budded setts with wide row $(120 \mathrm{~cm})$ planting $(138.2,159.5$ and $297.7 \mathrm{~kg} \mathrm{ha}^{-1}$, respectively). 
Table.1 Nitrogen content and uptake of sugarcane as influenced by different establishment techniques and planting geometries at harvest

\begin{tabular}{|c|c|c|c|c|c|}
\hline \multirow[t]{2}{*}{ Treatments } & \multicolumn{2}{|c|}{$\begin{array}{c}\text { Nitrogen content } \\
(\%)\end{array}$} & \multicolumn{3}{|c|}{ Nitrogen uptake $\left(\mathrm{kg} \mathrm{ha}^{-1}\right)$} \\
\hline & Leaf & Cane & Leaf & Cane & Total \\
\hline $\begin{array}{l}T_{1} \text { : Single eye budded setts with wide row } \\
\text { planting }(120 \mathrm{~cm} \text { furrow) }\end{array}$ & 1.1 & 0.4 & 91.2 & 161.9 & 253.2 \\
\hline $\begin{array}{l}T_{2} \text { : Single eye budded setts with paired } \\
\text { row planting }(60 \mathrm{~cm}-120 \mathrm{~cm}-60 \mathrm{~cm})\end{array}$ & 1.1 & 0.4 & 96.0 & 166.9 & 263.0 \\
\hline $\begin{array}{l}T_{3} \text { : Single eye budded setts with dual row } \\
\text { planting }(30 \mathrm{~cm}-150 \mathrm{~cm}-30 \mathrm{~cm})\end{array}$ & 1.1 & 0.4 & 96.7 & 169.0 & 265.7 \\
\hline $\begin{array}{l}T_{4} \text { : Two eye budded setts with wide row } \\
\text { planting }(120 \mathrm{~cm})\end{array}$ & 1.2 & 0.4 & 111.2 & 178.1 & 289.4 \\
\hline $\begin{array}{l}T_{5} \text { : Two eye budded setts with paired row } \\
\text { planting }(60 \mathrm{~cm}-120 \mathrm{~cm}-60 \mathrm{~cm})\end{array}$ & 1.2 & 0.4 & 120.1 & 188.8 & 308.9 \\
\hline $\begin{array}{l}\mathrm{T}_{6} \text { : Two eye budded setts with dual row } \\
\text { planting }(30 \mathrm{~cm}-150 \mathrm{~cm}-30 \mathrm{~cm})\end{array}$ & 1.2 & 0.4 & 133.2 & 204.2 & 337.4 \\
\hline $\begin{array}{l}\mathrm{T}_{7} \text { : Bud chip seedling with wide row } \\
\text { planting }(120 \mathrm{~cm} \text { furrow })\end{array}$ & 1.1 & 0.4 & 84.5 & 148.0 & 232.5 \\
\hline $\begin{array}{l}\mathrm{T}_{8} \text { : Bud chip seedling with paired row } \\
\text { planting }(60 \mathrm{~cm}-120 \mathrm{~cm}-60 \mathrm{~cm})\end{array}$ & 1.1 & 0.4 & 86.9 & 153.1 & 240.0 \\
\hline $\begin{array}{l}T_{9} \text { : Bud chip seedling with dual row } \\
\text { planting }(30 \mathrm{~cm}-150 \mathrm{~cm}-30 \mathrm{~cm})\end{array}$ & 1.1 & 0.4 & 87.6 & 154.6 & 242.3 \\
\hline $\begin{array}{l}\mathrm{T}_{10}: \text { Three eye budded setts with } \\
\text { conventional planting }(90 \mathrm{~cm})\end{array}$ & 1.0 & 0.4 & 78.1 & 143.2 & 221.3 \\
\hline S.Em. \pm & 0.1 & 0.0 & 11.3 & 9.3 & 13.7 \\
\hline C.D. $(\mathrm{P}=0.05)$ & NS & NS & 33.8 & 27.5 & 40.7 \\
\hline
\end{tabular}

NS: Non Significant 
Table.2 Phosphorus content and uptake of sugarcane as influenced by different establishment techniques and planting geometries at harvest

\begin{tabular}{|c|c|c|c|c|c|}
\hline \multirow[t]{2}{*}{ Treatments } & \multicolumn{2}{|c|}{$\begin{array}{l}\text { Phosphorus } \\
\text { content }(\%)\end{array}$} & \multicolumn{3}{|c|}{$\underset{1}{\text { Phosphorus uptake (kg ha }}$} \\
\hline & Leaf & Cane & Leaf & Cane & Total \\
\hline $\begin{array}{l}\mathrm{T}_{1} \text { : Single eye budded setts with wide row } \\
\text { planting }(120 \mathrm{~cm} \text { furrow })\end{array}$ & 0.2 & 0.1 & 17.6 & 43.5 & 61.2 \\
\hline $\begin{array}{l}T_{2} \text { : Single eye budded setts with paired } \\
\text { row planting }(60 \mathrm{~cm}-120 \mathrm{~cm}-60 \mathrm{~cm})\end{array}$ & 0.2 & 0.1 & 18.2 & 45.0 & 63.3 \\
\hline $\begin{array}{l}T_{3} \text { : Single eye budded setts with dual row } \\
\text { planting }(30 \mathrm{~cm}-150 \mathrm{~cm}-30 \mathrm{~cm})\end{array}$ & 0.2 & 0.1 & 18.6 & 45.3 & 64.0 \\
\hline $\begin{array}{l}\mathrm{T}_{4} \text { : Two eye budded setts with wide row } \\
\text { planting }(120 \mathrm{~cm})\end{array}$ & 0.2 & 0.1 & 20.6 & 48.4 & 69.0 \\
\hline $\begin{array}{l}T_{5} \text { : Two eye budded setts with paired row } \\
\text { planting }(60 \mathrm{~cm}-120 \mathrm{~cm}-60 \mathrm{~cm})\end{array}$ & 0.2 & 0.1 & 21.4 & 51.0 & 72.4 \\
\hline $\begin{array}{l}\mathrm{T}_{6} \text { : Two eye budded setts with dual row } \\
\text { planting }(30 \mathrm{~cm}-150 \mathrm{~cm}-30 \mathrm{~cm})\end{array}$ & 0.2 & 0.1 & 24.1 & 55.0 & 79.1 \\
\hline $\begin{array}{l}\mathrm{T}_{7} \text { : Bud chip seedling with wide row } \\
\text { planting ( } 120 \mathrm{~cm} \text { furrow) }\end{array}$ & 0.2 & 0.1 & 16.2 & 40.5 & 56.8 \\
\hline $\begin{array}{l}T_{8} \text { : Bud chip seedling with paired row } \\
\text { planting }(60 \mathrm{~cm}-120 \mathrm{~cm}-60 \mathrm{~cm})\end{array}$ & 0.2 & 0.1 & 16.8 & 42.0 & 58.9 \\
\hline $\begin{array}{l}T_{9} \text { : Bud chip seedling with dual row } \\
\text { planting }(30 \mathrm{~cm}-150 \mathrm{~cm}-30 \mathrm{~cm})\end{array}$ & 0.2 & 0.1 & 17.0 & 42.3 & 59.4 \\
\hline $\begin{array}{l}\mathrm{T}_{10} \text { : Three eye budded setts with } \\
\text { conventional planting }(90 \mathrm{~cm})\end{array}$ & 0.2 & 0.1 & 15.8 & 38.8 & 54.6 \\
\hline S.Em. \pm & 0.0 & 0.00 & 0.9 & 1.5 & 1.9 \\
\hline C.D. $(P=0.05)$ & NS & NS & 2.8 & 4.4 & 5.4 \\
\hline
\end{tabular}

NS: Non Significant 
Table.3 Potassium content and uptake of sugarcane as influenced by different establishment techniques and planting geometries at harvest

\begin{tabular}{|c|c|c|c|c|c|}
\hline \multirow[t]{2}{*}{ Treatments } & \multicolumn{2}{|c|}{$\begin{array}{l}\text { Potassium } \\
\text { content }(\%)\end{array}$} & \multicolumn{3}{|c|}{ Potassium uptake $\left(\mathrm{kg} \mathrm{ha}^{-1}\right)$} \\
\hline & Leaf & Cane & Leaf & Cane & Total \\
\hline $\begin{array}{l}\mathrm{T}_{1} \text { : Single eye budded setts with wide row } \\
\text { planting }(120 \mathrm{~cm} \text { furrow })\end{array}$ & 1.4 & 0.3 & 119.8 & 146.6 & 266.5 \\
\hline $\begin{array}{l}T_{2} \text { : Single eye budded setts with paired } \\
\text { row planting }(60 \mathrm{~cm}-120 \mathrm{~cm}-60 \mathrm{~cm})\end{array}$ & 1.4 & 0.3 & 123.8 & 150.9 & 274.8 \\
\hline $\begin{array}{l}T_{3} \text { : Single eye budded setts with dual row } \\
\text { planting }(30 \mathrm{~cm}-150 \mathrm{~cm}-30 \mathrm{~cm})\end{array}$ & 1.4 & 0.3 & 124.8 & 151.6 & 276.4 \\
\hline $\begin{array}{l}\mathrm{T}_{4} \text { : Two eye budded setts with wide row } \\
\text { planting }(120 \mathrm{~cm})\end{array}$ & 1.4 & 0.3 & 138.2 & 159.5 & 297.7 \\
\hline $\begin{array}{l}T_{5} \text { : Two eye budded setts with paired row } \\
\text { planting }(60 \mathrm{~cm}-120 \mathrm{~cm}-60 \mathrm{~cm})\end{array}$ & 1.4 & 0.3 & 142.3 & 167.7 & 310.1 \\
\hline $\begin{array}{l}\mathrm{T}_{6} \text { : Two eye budded setts with dual row } \\
\text { planting }(30 \mathrm{~cm}-150 \mathrm{~cm}-30 \mathrm{~cm})\end{array}$ & 1.4 & 0.3 & 160.5 & 181.0 & 341.6 \\
\hline $\begin{array}{l}\mathrm{T}_{7} \text { : Bud chip seedling with wide row } \\
\text { planting }(120 \mathrm{~cm} \text { furrow })\end{array}$ & 1.4 & 0.3 & 112.7 & 137.9 & 250.6 \\
\hline $\begin{array}{l}\mathrm{T}_{8} \text { : Bud chip seedling with paired row } \\
\text { planting }(60 \mathrm{~cm}-120 \mathrm{~cm}-60 \mathrm{~cm})\end{array}$ & 1.4 & 0.3 & 115.7 & 141.8 & 257.5 \\
\hline $\begin{array}{l}\mathrm{T}_{9} \text { : Bud chip seedling with dual row } \\
\text { planting }(30 \mathrm{~cm}-150 \mathrm{~cm}-30 \mathrm{~cm})\end{array}$ & 1.4 & 0.3 & 117.4 & 142.5 & 259.9 \\
\hline $\begin{array}{l}\mathrm{T}_{10}: \text { Three eye budded setts with } \\
\text { conventional planting }(90 \mathrm{~cm})\end{array}$ & 1.4 & 0.3 & 108.2 & 132.1 & 240.3 \\
\hline S.Em. \pm & 0.0 & 0.0 & 6.2 & 5.2 & 9.7 \\
\hline C.D. $(P=0.05)$ & NS & NS & 18.3 & 15.3 & 28.8 \\
\hline
\end{tabular}

NS: Non Significant 
Table.4 Chemical properties of soil influenced by different establishment techniques and planting geometries after Harvest of sugarcane

\begin{tabular}{|c|c|c|c|c|c|c|}
\hline \multirow[t]{2}{*}{ Treatments } & \multirow[t]{2}{*}{ pH } & \multirow{2}{*}{$\begin{array}{l}\text { Electrical conductivity } \\
\qquad\left(\mathrm{dS} \mathrm{m}^{-1}\right)\end{array}$} & \multirow{2}{*}{$\begin{array}{c}\text { Organic } \\
\text { carbon }(\%)\end{array}$} & \multicolumn{3}{|c|}{ Available nutrients $\left(\mathrm{kg} \mathrm{ha}^{-1}\right)$} \\
\hline & & & & $\mathbf{N}$ & $\mathrm{P}_{2} \mathrm{O}_{5}$ & K2O \\
\hline $\begin{array}{l}T_{1}: \text { Single eye budded setts with wide row planting } \\
(120 \mathrm{~cm} \text { furrow) }\end{array}$ & 8.1 & 0.3 & 0.4 & 170.0 & 38.7 & 270.2 \\
\hline $\begin{array}{l}T_{2} \text { : Single eye budded setts with paired row planting } \\
(60 \mathrm{~cm}-120 \mathrm{~cm}-60 \mathrm{~cm})\end{array}$ & 8.2 & 0.4 & 0.4 & 169.2 & 40.2 & 271.5 \\
\hline $\begin{array}{l}T_{3} \text { : Single eye budded setts with dual row planting } \\
(30 \mathrm{~cm}-150 \mathrm{~cm}-30 \mathrm{~cm})\end{array}$ & 8.2 & 0.4 & 0.4 & 169.1 & 38.4 & 268.9 \\
\hline $\begin{array}{l}\text { T4: Two eye budded setts with wide row planting } \\
(120 \mathrm{~cm})\end{array}$ & 8.4 & 0.4 & 0.4 & 167.2 & 38.3 & 267.3 \\
\hline $\begin{array}{l}\text { T5: Two eye budded setts with paired row planting } \\
(60 \mathrm{~cm}-120 \mathrm{~cm}-60 \mathrm{~cm})\end{array}$ & 8.3 & 0.4 & 0.4 & 165.0 & 38.2 & 267.0 \\
\hline $\begin{array}{l}\text { T6: Two eye budded setts with dual row planting (30 } \\
\text { cm-150 cm-30 cm) }\end{array}$ & 8.4 & 0.4 & 0.4 & 163.8 & 38.1 & 267.0 \\
\hline $\begin{array}{l}\text { T }_{7} \text { : Bud chip seedling with wide row planting (120 } \\
\text { cm furrow) }\end{array}$ & 8.1 & 0.4 & 0.4 & 173.7 & 42.1 & 271.1 \\
\hline $\begin{array}{l}\text { T8: Bud chip seedling with paired row planting (60 } \\
\text { cm-120 cm-60 cm) }\end{array}$ & 8.3 & 0.3 & 0.4 & 173.4 & 42.0 & 267.0 \\
\hline $\begin{array}{l}\text { T9: Bud chip seedling with dual row planting }(30 \mathrm{~cm}- \\
150 \mathrm{~cm}-30 \mathrm{~cm})\end{array}$ & 8.2 & 0.3 & 0.4 & 171.7 & 41.1 & 271.9 \\
\hline $\begin{array}{l}\mathrm{T}_{10}: \text { Three eye budded setts with conventional } \\
\text { planting }(90 \mathrm{~cm})\end{array}$ & 8.1 & 0.3 & 0.4 & 174.8 & 42.6 & 272.6 \\
\hline S.Em. \pm & 0.1 & $\mathbf{0 . 0}$ & $\mathbf{0 . 0}$ & 3.5 & 1.6 & 1.8 \\
\hline C.D. $(P=0.05)$ & NS & NS & NS & NS & NS & NS \\
\hline
\end{tabular}

NS: Non Significant 
However, uptake of potassium in leaf, cane and plant was on par with planting of sugarcane with single eye budded setts and bud chip seedling with different planting geometries.

Whereas, planting of sugarcane with three budded setts (conventional planting) recorded significantly lower uptake of potassium in leaf, cane and plant (108.2, 132.1 and 240.3 $\mathrm{kg} \mathrm{ha}^{-1}$, respectively). Similar findings were reported by Patel (2003).

\section{Changes in $\mathbf{N}, P$ and $K$ content in soil}

The data on chemical properties of soil after harvest of sugarcane viz., $\mathrm{pH}, \mathrm{EC}, \mathrm{OC}$, available nitrogen, phosphorus and potassium were not differed significantly as influenced by the establishment techniques and planting geometries (Table 4).

Similar findings were reported by Patel (2003).

The results of the investigation showed that, planting of two eye budded setts with dual row planting of sugarcane recorded numerically higher $\mathrm{N}$ and $\mathrm{K}$ uptake (337.4, 79.1 and $341.6 \mathrm{~kg} \mathrm{ha}^{-1}$, respectively) followed by two eye budded setts with paired row planting (308.9, 72.4 and $310.1 \mathrm{~kg} \mathrm{ha}^{-1}$, respectively) and two eye budded setts with wide row planting $(289.5,69.1$ and $297.7 \mathrm{~kg}$ $\mathrm{ha}^{-1}$, respectively).

Lower uptake was noticed in three eye budded setts with normal row planting (221.3, 54.6 and $240.3 \mathrm{~kg} \mathrm{ha}^{-1}$, respectively).

Under different establishment techniques and planting geometries, growing sugarcane did not significantly influence the available soil nutrients at harvest. However, three eye budded setts with normal planting recorded numerically higher $\mathrm{N}, \mathrm{P}$ and $\mathrm{K}$ availability followed by chip bud setts with wide row planting. Lower $\mathrm{N}, \mathrm{P}$ and $\mathrm{K}$ availability was recorded in two eye budded setts with dual row planting.

\section{References}

Anonymous, 2015, Area, production and productivity of sugarcane in India, $\mathrm{Co}$ operative Sugar, 47(3): 1-2.

Anonymous, 2015a, Annual progress report, Indian Institute of Sugarcane Research, Lucknow, India.

Anonymous, 2015b, Department of Food \& Public Distribution (for Sugar Production) and Agricultural Statistics (for production and area of Sugarcane). New Delhi

Gomez, K. A. and Gomez, A. A., 1984, Statistical Procedures for Agricultural Research, $2^{\text {nd }}$ Edn.. John Wiley and Sons. New York, p. 639.

Jackson M L. 1973. Soil chemical analysis. Prentice-Hall. Inc. Engle Wood Cliffs, New Jersey.

Lindsay W L and Norvel WA. 1978. Development of DTPA soil test for Zn, $\mathrm{Fe}, \mathrm{Mn}$ and $\mathrm{Cu}$. Soil Science Society of American Journal 42: 421-428.

Patel, D. D., 2003, Effect of planting geometry and weed management on sugarcane (Saccharum hybrid) var. CoN 85134 (Guj. Cane 2). Ph.D. thesis, submitted to Gujarath Agric. Univ., Navsari.

Patel, S. R., 2000, Effect of planting geometry, intercropping and weed management on sugarcane (Saccharum hybrid) var. CoN-91132 (Guj. Cane-1). Ph.D. thesis submitted to Gujarath Agric. Univ., S.K. Nagar, Navsari. 


\section{How to cite this article:}

Maruthi, D. Krishnamurthy, Y.M. Ramesh, B.M. Chittapur and Ashokkumar Gaddi. 2018. Effect of Different Establishment Techniques and Planting Geometry on Nutrient Content, Uptake and Soil Fertility Status after Harvest of Sugarcane. Int.J.Curr.Microbiol.App.Sci. 7(10): 94-102. doi: https://doi.org/10.20546/ijcmas.2018.710.011 